\title{
PENJADWALAN FLOWSHOP DENGAN MENGGUNAKAN SIMULATED ANNEALING
}

\author{
Muhammad Firdaus, Ilyas Masudin, Dana Marsetya Utama \\ Jurusan Teknik Industri - Universitas Muhammadiyah Malang \\ masudin@umm.ac.id
}

\begin{abstract}
This article apply a machine scheduling technique, named Simulate Annealing (SA) to schedule 8 jobs and 5 machines to minimize makespan. A flowshop production flow is chosen as a case study to collect data and attempted to reduce jobs' makespan. This article also does a sensitivity analysis to explore the implication of the changes of SA parameters as temperature. The results shows that the completion time of the jobs uses SA algoritm can decrease the completion time of the jobs, about 5 hours lower than the existing method. Moreover, total idle time of the machines is also reduced by 2.18 per cent using SA technique. Based on the sensitivity analysis, it indicates that there is a significant relationship between the changes of temperatures and makespan and computation time.
\end{abstract}

Keywords : scheduling,simulated annealing, makespan flow shop.

\section{PENDAHULUAN}

Hampir semua permasalahan utama dari lantai produksi flowshop sebuah perusahaan adalah masalah penjadwalan produksi, terutama dalam menentukan efisiensi urutan pekerjaan (jobs) yang akan dikerjakan. Kegagalan dalam menjadwalkan urutan pengerjaan jobs pada mesin akan mengakibatkan keterlambatan penyelesaian jobs dan rendahnya utilitas mesin yang pada akhirnya akan mengakibatkan biaya produksi yang tinggi. Oleh karena itu, metode penjadwalan mesin bisa menjadi salah satu alternative cara untuk menyelesaikan permasalah penjadwalan job dan mesin. Salah satu metode penjadwalan job dan mesin yang cukup popular adalah Simulated Annealing (SA). Menurut Ratnasari (2007), masalah penjadwalan produksi flow shop terbukti dapat diselesaikan menggunakan algoritma Simulated Annealing (SA) dengan tujuan meminimalkan makespan dan total flow time, selain itu menurut Santoso (2012), algoritma Simulated Annealing dapat diterapkan dengan baik dalam penjadwalan produksi yang digolongkan ke dalam flow shop. Tidak hanya dapat diterapkan, algoritma ini bahkan sangat efektif karena mampu mengatasi penjadwalan dengan jumlah job banyak (15 job) dengan waktu proses yang relative cepat dan hasil penjadwalan yang baik, dan juga menurut Damanik (2011), dengan penjadwalan usulan dengan metode algoritma Simulated Annealing menghasilkan makespan 13\% lebih kecil dari penjadwalan awal dan dengan metode ini penjadwalan job dapat terpenuhi, dan tidak terjadi keterlambatan.

Dengan mengacu pada permasalahan diatas dan juga pada penelitian - penelitian sebelumnya, maka artikel ini berusaha memberikan usulan penyelesaian problem penjadwalan jobs pada lantai produksi flowshop dengan Simulated Annealing (SA). Artikel ini berbasis case study yang akan merencanakan penjadwalan produksi agar bisa meminimalkan waktu penyelesaian produksi, sehingga perusahaan dapat mengirimkan barang sesuai dengan waktu yang ditentukan dan dapat meminimalkan biaya yang dikeluarkan karena mesin yang digunakan dapat digunakan dengan optimal. Pada penelitian ini, penjadwalan produksi menggunakan metode simulated annealing (SA) sedangkan teknik pengacakannya menggunakan yaitu metode swap (menukar), flip (membalik), dan slide (menggeser). dengan menggunakan bantuan software matlab diharapkan bisa menyelesaikan permasalahan yang dialami perusahaan. 


\section{LANDASAN TEORI}

\section{A. Studi Pustaka}

Menurut Baker (1974), pengertian penjadwalan secara umum didefenisikan sebagai proses penggalokasian sumber untuk memilih sekumpulan tugas dalam jangka waktu tertentu. Sedangkan menurut Ginting (2009), penjadwalan adalah pengurutan pembuatan/pengerjaan produk secara menyeluruh yang dikerjakan pada beberapa buah mesin. Dengan demikian masalah sequencing senantiasa melibatkan pengerjaan sejumlah komponen yang sering disebut dengan istilah 'job'. Job sendiri masih merupakan komposisi dari sejumlah elemen-elemen dasar yang disebut aktivitas atau operasi ini membutuhkan alokasi sumber daya tertentu selama periode waktu tertentu yang sering disebut dengan waktu proses.

Permasalahan muncul apabila ada tahapan operasi tertentu beberapa atau seluruh pekerjaan itu membutuhkan stasiun kerja yang sama. Dengan dilakukannya pengurutan pekerjaan ini unit-unit produksi (resource) dapat dimanfaatkan secara optimum. Pemanfaatan ini antara lain dilakukan dengan jalan meningkatkan utilitas unit-unit produksi melalui usaha-usaha mereduksi waktu menganggur (idle time) dari unit-unit yang bersangkutan. Juga dapat dilakukan dengan cara meminimumkan inprocess inventory melalui reduksi terhadap waktu rata - rata pekerjaan yang menunggu dalam baris antrian pada unit - unit produksi.

Menurut Uttari (2008), beberapa istilah umum yang digunakan dalam penjadwalan produksi adalah sebagai berikut :

Processing time $\left(\mathrm{t}_{\mathrm{i}}\right)$

Merupakan perkiraan waktu penyelesaian satu pekerjaan. Perkiraan waktu ini meliputi juga perkiraan waktu set-up yang dibutuhkan. Symbol yang digunakan untuk waktu proses pekerjaan I adalah $\mathrm{t}_{\mathrm{i}}$.

Makespan (Ms)

Adalah jangka waktu penyelesaian suatu penjadwalan yang merupakan jumlah seluruh waktu proses.

Flow time $(\mathrm{Fi})$

$$
M s=\sum_{i=1}^{n} t_{i}
$$

Merupakan rentang waktu antara saat pekerjaan tersedia (dapat dimulai) dan saat pekerjaan selesai. Waktu alir sama dengan waktu proses ditambah waktu tunggu sebelum pekerjaan diproses.

$$
\begin{aligned}
& \mathrm{F}_{\mathrm{i}}=\mathrm{t}_{\mathrm{i}}+\mathrm{W}_{\mathrm{i}} \\
& \mathrm{F}_{\mathrm{i}}=\mathrm{C}_{\mathrm{i}}+\mathrm{r}_{\mathrm{i}}
\end{aligned}
$$

\section{Completion time $\left(\mathrm{C}_{\mathrm{i}}\right)$}

Merupakan rentang waktu antara saat pekerjaan dimulai $(\mathrm{t}=0)$, sampai dengan pekerjaan itu selesai.

$$
\mathrm{C}_{\mathrm{i}}=\mathrm{F}_{\mathrm{i}}+\mathrm{r}_{\mathrm{i}}
$$

Rata-rata flow time

Due date $\left(\mathrm{d}_{\mathrm{i}}\right)$

$$
\bar{F}=\frac{1}{n} \sum_{f=1}^{n} F_{j}
$$

Merupakan waktu maksimal yang dapat diteima untuk menyelesaikan pekerjaan tersebut. Kelebihan waktu dari waktu yang ditetapkan, merupakan suatu kelambatan.

Lateness $\left(\mathrm{L}_{\mathrm{i}}\right)$

Merupakan penyimpangan antara waktu penyelesaian pekerjaan dengan batas waktu. Suatu pekerjaan akan mempunyai kelambatan positif jika diselesaikan sesudah batas waktu dan kelambatan negatif jika diselesaikan sebelum batas waktu. 
$\mathrm{L}_{\mathrm{i}}=\mathrm{C}_{\mathrm{i}}-\mathrm{d}_{\mathrm{i}}$

$\mathrm{L}_{\mathrm{i}}<0$, saat penyelesaian memenuhi batas akhir

$\mathrm{L}_{\mathrm{i}}>0$, saat penyelesaian melewati batas akhir

Rata-rata lateness

$$
\overline{\mathrm{LS}}=\sum_{\mathrm{j}=1}^{\mathrm{n}}\left(\mathrm{C}_{\mathrm{i}}-\mathrm{d}_{\mathrm{i}}\right)
$$

Tardiness $\left(\mathrm{T}_{\mathrm{i}}\right)$

Merupakan ukuran kelambatan positif. Jika suatu pekerjaan diselesaikan lebih cepat dari batas waktu yang ditetapkan, maka mempunyai nilai kelambatan negatif tetapi ukuran kelambatan positif. Ukuran ini disimbolkan dengan $T_{i}$ dimana $T_{i}$ adalah maksimum dari $\left(0, \mathrm{~L}_{\mathrm{i}}\right)$.

Rata-rata tardiness

Slack time $\left(\mathrm{SL}_{\mathrm{i}}\right)$

$$
\bar{T}_{\mathrm{s}}=\frac{1}{\mathrm{n}} \sum_{\mathrm{j}=1}^{\mathrm{n}} \mathrm{T}_{\mathrm{j}}
$$

Merupakan ukuran yang digunakan untuk melihat selisih waktu antara waktu proses dengan batas waktu yang sudah ditetapkan.

$$
\mathrm{S}_{\mathrm{i}}=\mathrm{d}_{\mathrm{i}}-\mathrm{t}_{\mathrm{i}}
$$

\section{B. Simulated Annealing (SA)}

Santosa dan Willy (2011), Annealing adalah satu teknik yang dikenal dalam bidang metalurgi, digunakan dalam mempelajari proses pembentukan kristal dalam suatu materi. Agar dapat terbentuk susunan kristal yang sempurna, diperlukan pemanasan sampai suatu tingkat tertentu, kemudian dilanjutkan dengan pendinginan yang perlahanlahan dan terkendali dari materi tersebut. Pemanasan materi di awal proses annealing, memberikan kesempatan pada atom-atom dalam materi itu untuk bergerak secara bebas, mengingat tingkat energi dalam kondisi panas ini cukup tinggi. Proses pendinginan yang perlahan-lahan memungkinkan atom-atom yang tadinya bergerak bebas itu, pada akhirnya menemukan tempat yang optimum, di mana energi internal yang dibutuhkan atom itu untuk mempertahankan posisinya adalah minimum.

Simulated Annealing berjalan berdasarkan analogi dengan proses annealing yang telah dijelaskan diatas. Pada awal proses SA, dipilih suatu solusi awal, yang merepresentasikan kondisi materi sebelum proses dimulai. Gerakan bebas dari atomatom pada materi, direpresentasikan dalam bentuk modifikasi terhadap solusi awal/solusi sementara. Pada awal proses SA, saat parameter suhu (T) diatur tinggi, solusi sementara yang sudah ada diperbolehkan untuk mengalami modifikasi secara bebas.

Kebebasan ini secara relatif diukur berdasarkan nilai fungsi tertentu yang mengevaluasi seberapa optimal solusi sementara yang telah diperoleh. Bila nilai fungsi evaluasi hasil modifikasi ini membaik (dalam masalah optimisasi yang berusaha mencari minimum berarti nilainya lebih kecil/downhill) solusi hasil modifikasi ini akan digunakan sebagai solusi selanjutnya. Bila nilai fungsi evaluasi hasil modifikasi ini memburuk, pada saat temperatur annealing masih tinggi, solusi yang lebih buruk (uphill) ini masih mungkin diterima. Dalam tahapan selanjutnya saat temperatur sedikit demi sedikit dikurangi, maka kemungkinan untuk menerima langkah modifikasi yang tidak memperbaiki nilai fungsi evaluasi semakin berkurang. Sehingga kebebasan untuk memodifikasi solusi semakin menyempit, sampai akhirnya diharapkan diperoleh solusi yang mendekati solusi optimal. 
Metode SA meniru proses pendinginan secara perlahan baja / metal yang mendidih untuk mencapai nilai minimum fungsi dalam permasalahan minimasi. Proses pendinginan ini ditiru dengan cara menentukan parameter yang serupa dengan suhu lalu mengontrolnya dengan menggunakan dengan mengunakan konsep distribusi probabilitas Boltzmann. Distribusi probabilitas Boltzmann menyatakan bahwa energi (E) dari suatu system dalam keseimbangan panas pada suhu $T$ terdistribusi secara probalistik mengikuti rumus

$$
P(E)=e^{-E / k T}
$$

Dimana $P(E)$ menyatakan peluang mencapai tingkat energi $E, T$ adalah dan $k$ konstanta Boltzmann. Pada persamaan ini menunjukkan bahwa jika proses pencairan solusi mengikuti distribusi probabilitas Boltzmann konvergensi algoritma SA dapat diatur dengan menggunakan temperatur $T$.

Metode yang mengimplementasikan distribusi probabilistic Boltzmann dalam simulated thermodynamic systems, seperti diusulkan Metropolis dkk yang dikutip dalam (Rao,2009), bisa juga ditetapkan dalam korteks minimasi fungsi. Dalam minimasi fungsi, misalkan solusi yang sekarang adalah $x$ dan nilai fungsinya $f(x)$, mirip dengan status energi pada system thermodinamika, energi $E_{i}$ pada status $x_{i}$ adalah

$$
E_{i}=f_{i}=f\left(x_{i}\right)
$$

Menurut kriteria Meropolis, probabilistic titik solusi berikutnya adalah $x_{i+1}$ bergantung pada perbedaan status energi atau fungsi tujuan dia dua titik (status) diberikan oleh

Dimana

$$
P\left[E_{i+1}\right]=\min \left\{1, e^{-\Delta E / k T}\right\},
$$

$$
\Delta E=E_{i+1}-E_{i}=\Delta f=f_{i+1}-f_{i}=f\left(x_{i+1}\right)-f\left(x_{i}\right)
$$

Titik baru bisa ditemukan dengan menggunakan distribusi probabilitas Boltzmann tersebut. Untuk faktor Boltzmann, $k$, bisa diberi nilai 1 . Jika $\Delta E \leq 0$, maka $P\left[E_{i+1}\right]=1$ sehingga titik $x_{i+1}$ selalu diterima. Ini adalah pilihan yang masuk akal dalam konteks minimasi fungsi, yaitu jika $f\left(x_{i+1}\right) \leq f\left(x_{i}\right)$ maka $x_{i+1}$ pasti diterima. Dilain pihak jika $\Delta E \leq 0$, maka nilai $f\left(x_{i+1}\right)$ akan lebih besar (lebih buruk) dari $f\left(x_{i}\right)$. dalam optimasi konvensional jika ini terjadi maka $x_{i+1}$ akan ditolak. Tetapi dalam SA ini masih diterima dengan Probabilitas $P$

$$
P\left[E_{i+1}\right]=e^{-\Delta E / k T}
$$

Dari persamaan diatas bisa dilihat bahwa pada temperatur $T$ tinggi maka peluang menerima $x_{i+1}$ dengan $\Delta E$ yang lebi besar akan besar. Dengan menurunnya temperatur $T$ probabilitas untuk menerima titik $x_{i+1}$ yang lebih buruk dari titik sebelumya akan mengecil. Sehingga jika temperatur semakin rendah (semakin dekat ke titik optimal), peluang suatu solusi $x_{i+1}$ dengan nilai $f$ lebih besar dibanding pada titik $x_{i}$ akan semakin kecil.

\section{Algoritma Simulated Annealing}

Santosa dan Willy (2011), Algoritma SA dapat dijelaskan secara ringkas sebagai berikut. Algoritma Simulated Annealing dimulai dengan suatu vektor solusi $\mathrm{x}_{1}$ (iterasi $\mathrm{i}=1$ ) dan nilai temperature $\mathrm{T}$ yang cukup tinggi. Bangkitkan vector solusi baru secara random yang dekat dari titik sekarang dan hitung perbedaan nilai fungsi tujuannya : 


$$
\Delta E=\mathrm{E}_{\mathrm{i}+1}-\mathrm{E}_{\mathrm{i}}=\Delta f=\mathrm{f}_{\mathrm{i}+1}-\mathrm{f}_{\mathrm{i}}=\mathrm{f}\left(\mathrm{x}_{\mathrm{i}+1}\right)-\mathrm{f}\left(\mathrm{x}_{\mathrm{i}}\right)
$$

Jika $\mathrm{f}_{\mathrm{i}+1}$ lebih kecil dari $\mathrm{f}_{\mathrm{i}}$ (dengan nilai $\Delta f$ negatif), terima titik $\mathrm{f}_{\mathrm{i}+1}$ sebagai titik solusi baru. Sebaliknya, jika nilai $\Delta f$ positif, probabilitas menerima $\mathrm{x}_{\mathrm{i}+1}$ sebagai solusi baru adalah $e^{-\Delta f / k T}$. Untuk meneria atau tidak, perlu dicari pembanding terhadap nilai probabilitas ini. Kita perlu membangkitkan bilangan random antara 0 sampai 1.

Apabila nilai random yang dibangkitkan ini lebih kecil dari nilai $e^{-\Delta f / k T}$, terima titik $\mathrm{x}_{\mathrm{i}+1}$; Sebaliknya, tolak $\mathrm{x}_{\mathrm{i}+1}$. Sampai disini kita telah menjalani satu iterasi dari algoritma SA. Jika titik $\mathrm{x}_{\mathrm{i}+1}$ ditolak, maka dilanjutkan proses pembangkitan nilai baru $\mathrm{x}_{\mathrm{i}+1}$ secara random dalam area yang berdekatan dengan titik sekarang $\mathrm{x}_{\mathrm{i}}$ dalam batas - batas tertentu, lalu mengevaluasi nilai fungsi tujuan $f_{i+1}$, dan memutuskan untuk menerima $\mathrm{x}_{\mathrm{i}+1}$ sebagi titik baru, berdasarkan criteria metropolis $\mathrm{P}\left[\mathrm{E}_{\mathrm{i}+1}\right]=e^{-\Delta f / k T}$. Untuk mensimulasikan pencapaian equilibrium thermal pada setiap temperatur tertentu T. jika jumlah titik $\mathrm{x}_{\mathrm{i}+1}$ yang diuji pada sembarang temperature $\mathrm{T}$ melebihi nilai $\mathrm{n}$, temperature T dikurangi dengan proporsi tertentu yaitu $\mathrm{c}(0<\mathrm{c}<1)$ dan seluruh proses diulang lagi. Prosedur ini diasumsikan akan mengalami konvergensi ketika temperature $\mathrm{T}$ yang dicapai cukup kecil atau jika perubahan nilai fungsi tujuan $(\Delta f)$ sudah sangat kecil.

Pilihan nilai awal temperature $\mathrm{T}$, jumlah iterasi $k$ sebelum mengurangi temperatur, dan faktor pengurangan temperatur $c$ adalah parameter - parameter penting dalam keberhasilan pelaksanaan algoritma SA. Jika misalnya nilai awal temperatur terlalu tinggi, maka dibutuhkan lebih banyak pengurangan temperature untuk konvergen. Sebaliknya jika nilai awal ini terlalu kecil proses pencairan ini mungkin kurang sempurna sehingga ada titik-titik potensial yang bisa menjadi global optimum terlewati. Faktor pereduksi temperatur c memainkan peran yang sama. Jika terlalu besar (0.8 atau 0.9) akan memerlukan terlalu banyak langkah komputasi. Sebaliknya, jika terlalu kecil nilai c (misal 0.1 atau 0.2 ) bisa berakibat terlalu cepatnya penurunan temperatur sehingga akan banyak titik-titik potensial untuk menjadi solusi global akan terlewati.

Sebaliknya jika terlalu kecil proses pencarian mungkin kurang sempurna sehingga ada titik - titik potensial yang bisa menjadi global optimum terlewati. Begitu juga jika jumlah iterasi $k$ terlalu besar akan membantu mencapai keseimbangan termal pada setiap temperatur tetapi dengan tambahan jumlah komputasi. Jika jumlah $n$ sedikit, maka bisa terjadi konvergensi yang terlalu cepat atau menuju kesolusi tetapi local optimum. Sayangnya tidak ada nilai $\mathrm{T}, \mathrm{n}$, dan c yang unik yang akan sesuai untuk semua problem. Tetapi ada beberapa cara untuk mendapatkan nilai yang cukup baik. Misalnya untuk $\mathrm{T}$ bisa dipilih dari nilai rata-rata dari fungsi tujuan yang dihitung pada sejumlah solusi awal yang dipilih secara random. Jumlah iterasi k bisa dipilih antara 50 dan 100 berdasarkan pada akurasi solusi yang diinginkan. Faktor pereduksi temperatur c bisa dipilih antara 0.4 dan 0.6 untuk strategi pengurangan temperatur yang masuk akal (cooling schedule). Gambar 1 menunjukkan langkah-langkah dari Algoritma simulated annealing (SA). Dalam SA, perlu diperhatikan adalah adanya langkah khusus untuk keluar dari local optimum. Langkah ini berupa penerimaan suatu titik $\mathrm{x}_{i+1}$ dengan peluang $e^{-\Delta f / k T}$ walaupun nilai fungsi pada titik ini tidak lebih dari titik sebelumnya $\mathrm{x}_{\mathrm{i}}$. ini dilakukan dengan harapan pada langkah selanjutnya akan dicapai suatu titik dengan nilai fungsi yang lebih baik lagi. Jika langkah khusus ini tidak ada, maka SA akan seperti teknik optimasi konvensional biasannya tidak bisa keluar dari local search trap. Hal-hal yang bisa dicatat dalam SA antara lain, pertama, solusi akhir tidak dipengaruhi solusi awal yang dimasukkan. Tetapi jika titik awal yang dimasukkan tidak cukup baik maka diperlukan waktu lebih lama untuk mencapai solusi akhirnya dan kedua, konvergensi tidak dipengaruhi konveksitas dari ruang pencarian yang (fleasible space). 


\section{METODOLOGI PENELITIAN}

Tahap pertama metodologi penelitian adalah menentukan teknik pengumpulan data, dimana dalam artikel ini beberapa data utama dikumpulkan meliputi data proses pembuatan produk yang dinyatakan sebagai job.

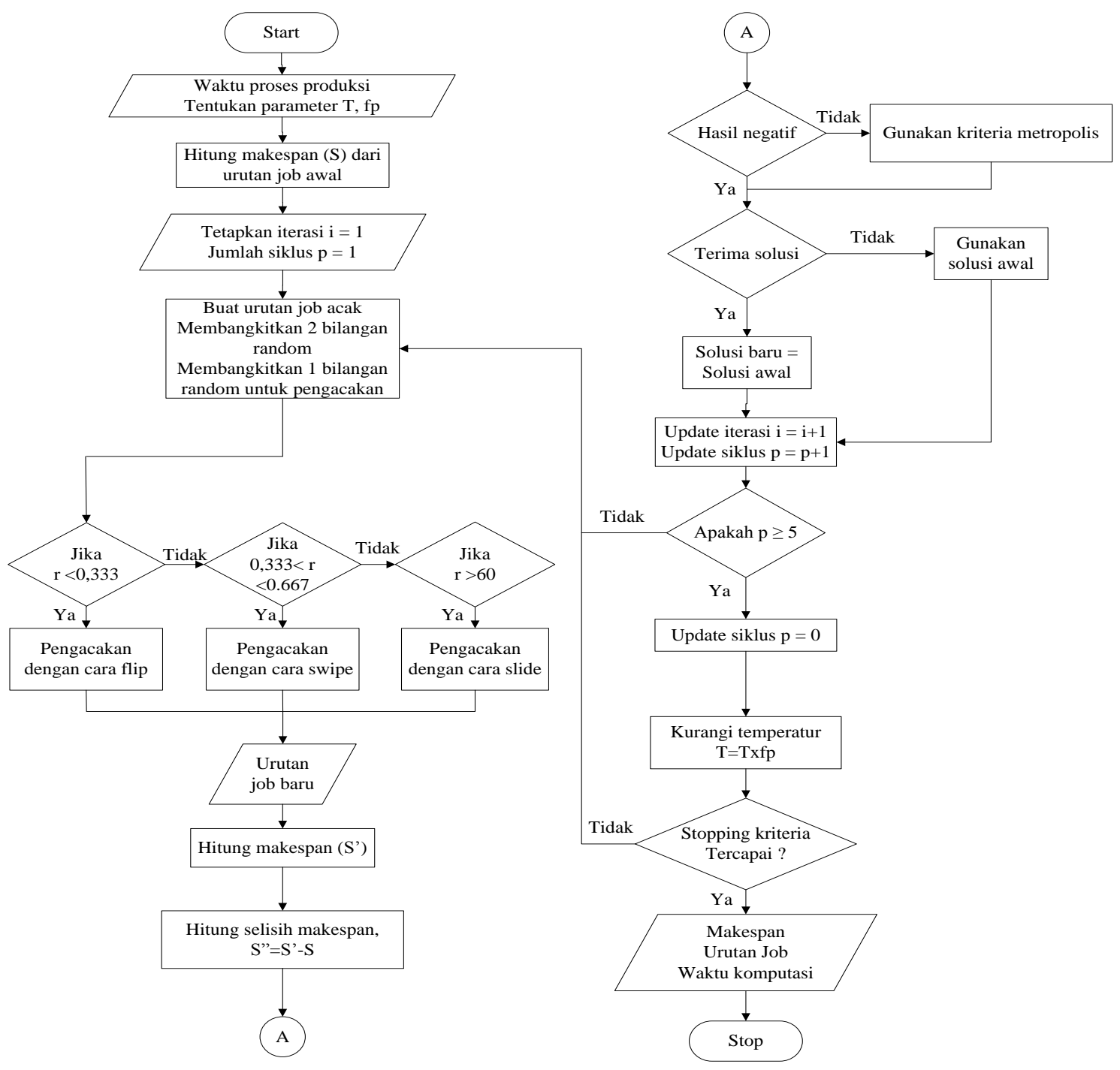

Gambar 1 Flowchart flow shop simulated annealing

Beberapa data yang diperlukan antara lain data mesin-mesin yang dipakai yang meliputi data mesin, jumlah mesin, spesifikasi mesin, yang berisi kapasitas mesin dan juga urutan proses pengerjaan serta waktu proses permesinan tiap job. Beberapa data tersebut didapatkan dengan langsung melakukan pengamatan atau observasi seperti data waktu permesianan tiap job dan urutan proses pengerjaan job di tiap mesin sementara beberapa data diantaranya merupakan sekunder yang disediakan oleh perusahaan seperti data kapasitas mesin dan spesifikasi mesin.

Tahap berikutnya melakukan penjadwalan dengan algoritma Simulated Annealing, dimana metode ini bertujuan untuk meminimalkan makespan dengan cara menentukan suhu awal dan penurunan suhu untuk selanjutnya dilakukan urutan job acak dengan cara membangkitkan 2 bilangan random untuk urutan mana saja yang nanti akan dirubah. Detail algoritma simulated annealing dapat dijelaskan dalam flowchart di diatas. 
Pada tahap selanjutnya, dilakukan coding memnggunakan software Matlab untuk dilakukan analisa senstivitas untuk melihat pengaruh perubahan atau penuruan suhu yang dilakukan dengan suhu awal (T) 100, 200, 300, 500 1000, faktor penurunan suhu (fp) 0.2, 0.5, 09 dengan kriteria pemberhentian suhu 0.0000001 dan jumlah siklus dalam 1 penurunan suhu sebanyak 5 kali terhadap waktu komputasi, jumlah iterasi dan makespan.

\section{HASIL DAN PEMBAHASAN}

Pada dasarnya keunggulan metode Simulated Annealing (SA) yaitu dapat mendapatkan urutan job yang lebih optimal karena hasil makespan darri perusahaan dijadikan inputan untuk kemudian diproses dalam penurunan suhu dimana dalam 1 siklus penurunan suhu tersebut didapatkan solusi baru yang nantinnya akan dibandingkan dengan solusi yang lama apakah lebih baik atau tidak, jika misalkan kurang baikpun maka hasil makespan dari SA ini akan sama dengan makespan awal. Berdasarkan hasil perhitungan SA manual maupun output program MATLAB berbasis SA pada kasus flow shop telah menghasilkan solusi optimal, akan tetapi dalam melakukan perhitungan SA manual akan membutuhkan waktu yang sangat lama karena harus dilakukan perhitungan secara bertahap, oleh karena itu dibutuhkan program matlab untuk membantu melakukan penjadwalan produksi. Keunggulan penggunaan SA dengan program Matlab yaitu dapat mempermudah dan mempercepat dalam melakukan penyelesaian pencarian solusi yang optimal, dari hasil running Matlab didapatkan waktu komputasi yang sangat cepat. Sehingga dari hasil tersebut diharapkan perusahaan dapat dengan cepat mengetahui kinerja penjadwalannya.

Tabel 1 Perbandingan Hasil Penjadwalan Komputasi Matlab

\begin{tabular}{cccccc}
\hline \multicolumn{2}{c}{ Parameter } & Makespan & Urutan Job & Iterasi & $\begin{array}{c}\text { Waktu } \\
\text { Komputasi }\end{array}$ \\
\hline \multirow{3}{*}{$\mathbf{T}=\mathbf{1 0 0}$} & $\mathrm{fp}=0.2$ & 2732 & $3-2-5-6-1-8-4-7$ & 66 & 0.0156 \\
& $\mathrm{fp}=0.5$ & 2636 & $5-7-8-2-3-1-6-4$ & 151 & 0.0156 \\
& $\mathrm{fp}=0.9$ & 2642 & $5-8-3-1-2-6-4-7$ & 986 & 0.1404 \\
\hline \multirow{4}{*}{$\mathbf{T}=\mathbf{2 0 0}$} & $\mathrm{fp}=0.2$ & 2702 & $5-2-3-8-6-4-1-7$ & 71 & 0.0312 \\
& $\mathrm{fp}=0.5$ & 2636 & $5-7-2-3-1-8-6-4$ & 156 & 0.0312 \\
& $\mathrm{fp}=0.9$ & 2642 & $5-2-8-1-3-6-4-7$ & 1021 & 0.1248 \\
\hline \multirow{3}{*}{$\mathbf{T}=\mathbf{5 0 0}$} & $\mathrm{fp}=0.2$ & 2710 & $5-2-1-7-6-4-8-3$ & 71 & 0.0156 \\
& $\mathrm{fp}=0.5$ & 2636 & $5-3-7-2-8-1-6-4$ & 166 & 0.0468 \\
& $\mathrm{fp}=0.9$ & 2636 & $5-8-3-2-7-1-6-4$ & 1061 & 0.1404 \\
\hline \multirow{2}{*}{$\mathbf{T}=\mathbf{1 0 0 0}$} & $\mathrm{fp}=0.2$ & 2672 & $3-5-1-2-6-8-4-7$ & 76 & 0.0312 \\
& $\mathrm{fp}=0.5$ & 2636 & $5-3-1-8-7-2-6-4$ & 171 & 0.0468 \\
& $\mathrm{fp}=0.9$ & 2636 & $5-7-3-8-2-1-6-4$ & 1096 & 0.1404 \\
\hline
\end{tabular}

Penjadwalan SA yang terdiri dari job1, job2, job3, job4, job5, job 6, job7, job8 digunakan parameter-parameter seperti suhu awal (T) dan faktor pereduksi suhu (fp) untuk pencarian solusi yang optimal. Menurut Santosa dan Willy (2011), Jika misalnya nilai awal temperatur terlalu tinggi, maka dibutuhkan lebih banyak pengurangan temperature untuk konvergen. Sebaliknya jika nilai awal ini terlalu kecil proses pencairan ini mungkin kurang sempurna sehingga ada titik-titik potensial yang bisa menjadi global optimum terlewati. 
Faktor pereduksi temperatur c memainkan peran yang sama. Jika terlalu besar ( 0.8 atau $0.9)$ akan memerlukan terlalu banyak langkah komputasi. Sebaliknya, jika terlalu kecil nilai (misal 0.1 atau 0.2) bisa berakibat terlalu cepatnya penurunan temperatur sehingga akan banyak titik-titik potensial untuk menjadi solusi global akan terlewati. Dengan mengacu pada penelitian-penelitian sebelumnya yang sudah membahas tentang penjadwalan dengan metode SA yaitu dengan menggunakan T100, T200, T500 dan T1000. Dari keempat parameter $\mathrm{T}$ tadi setiap parameter $\mathrm{T}$ dilakukan uji coba faktor pereduksi suhu (fp) $0.2,0.5$, dan 0.9 didapat makespan seperti pada tabe 11 .

Penjadwalan dengan metode SA ini dilakukan dengan bantuan komputasi matlab yang menggunakan beberapa parameter suhu $\mathrm{T}=100, \mathrm{~T}=200, \mathrm{~T}=500, \mathrm{~T}=1000$ dan pada tiap parameter $\mathrm{T}$ digunakan $\mathrm{fp}$ sebesar 0.2, 0.5, 0.9 didapat makespan terkecil yaitu sebesar 2636.

Dari perbandingan parameter diatas yang bisa dijadikan sebagai solusi usulan adalah pada suhu $\mathrm{T} 100$ dengan urutan proses produksi 5-7-8-2-3-1-6-4 karena dengan suhu yang rendah dibandingan yang lain pada suhu $\mathrm{T} 100$ ini sudah mendapat solusi yang optimum yaitu menghasilkan makespan 2636 menit $\approx 44$ jam yang hanya membutuhkan iterasi sebanyak 151 kali dan waktu komputasi yang dihasilkan paling cepat yaitu 0.0468 detik. Untuk Gantt Chart bisa dilihat pada gambar dibawah ini.

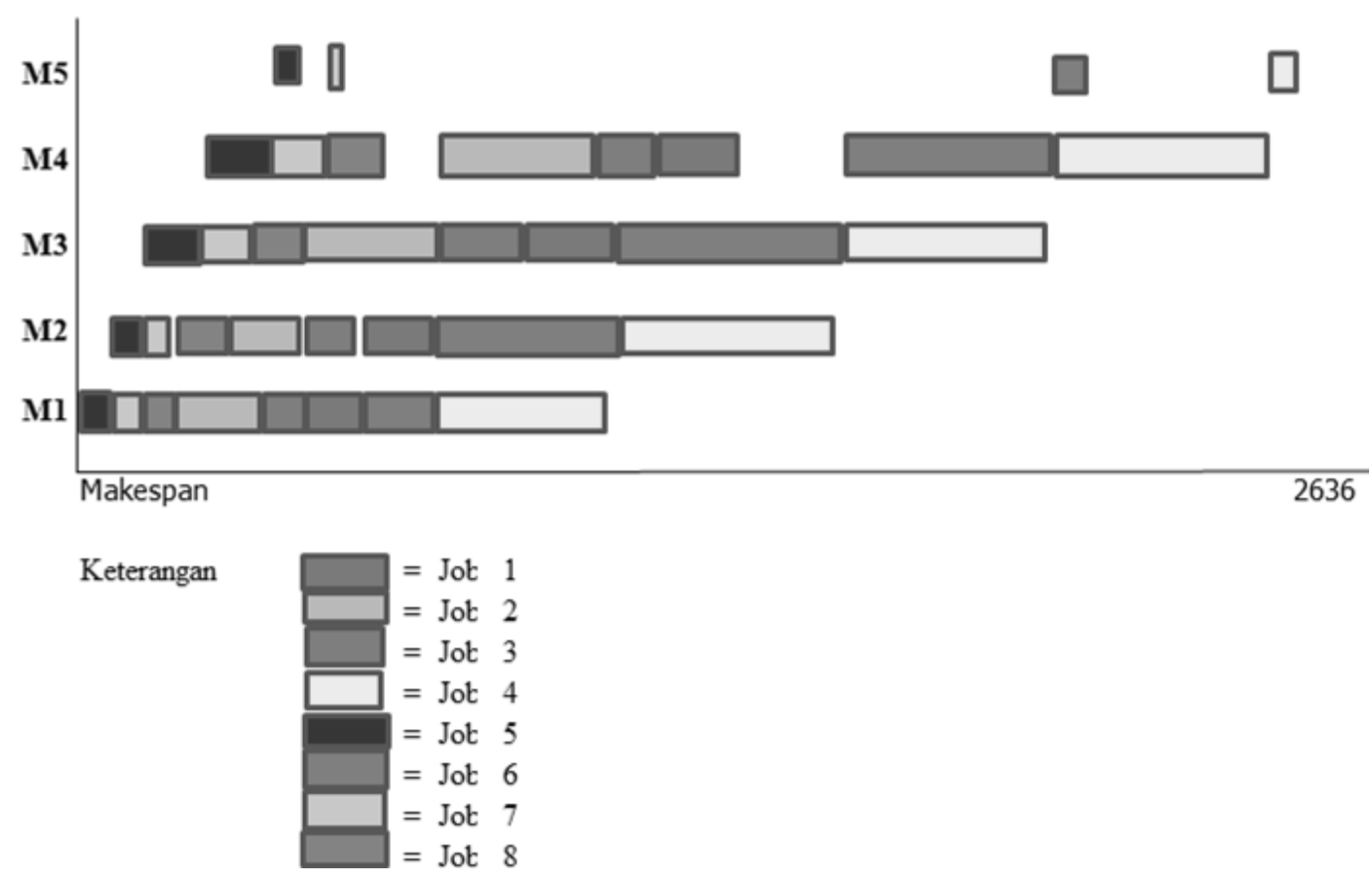

Gambar 2 Gambar Gantt Chart Penjadwalan Simulated Annealing

Dari Gambar Gantt Chart diatas dapat dihitung total idle time dari penjadwalan Simulated Annealing pada mesin 1 sebesar $=1558$ menit $\approx 26 \mathrm{jam}$, mesin $2=1281 \approx 21 \mathrm{jam}$, mesin 3 $=726 \approx 12 \mathrm{jam}$, mesin $4=621 \approx 10 \mathrm{jam}$, mesin $5=2180 \approx 36 \mathrm{jam}$.

\section{A. Analisa Sensitifitas}

Analisis sensitivitas merupakan analisis yang berkaitan dengan perubahan diskrit parameter untuk melihat berapa besar perubahan dapat ditolerir sebelum solusi optimum mulai kehilangan optimalitasnya. Jika suatu perubahan kecil dalam parameter menyebabkan perubahan drastis dalam solusi, dikatakan bahwa solusi sangat sensitive terhadap nilai parameter tersebut. Sebaliknya, jika perubahan parameter tidak mempunyai pengaruh besar terhadap solusi dikatakan solusi relative insensitive terhadap nilai parameter itu. 
Dalam penelitihan ini parameter-parameter yang digunakan adalah parameter suhu (T) dan parameter faktor pereduksi suhu (fp). Berikut grafik perbandingan $\mathrm{T} 100$, T 200, T 500, dan T 1000. Dimana pada setiap suhu (T) digunakan faktor penurunan suhu (fp) 0.2, 0.5, dan 0.9 yang nantinya parameter-parameter ini akan dilihat seberapa besar perubahannya dengan makespan, jumlah iterasi, dan waktu komputasi.

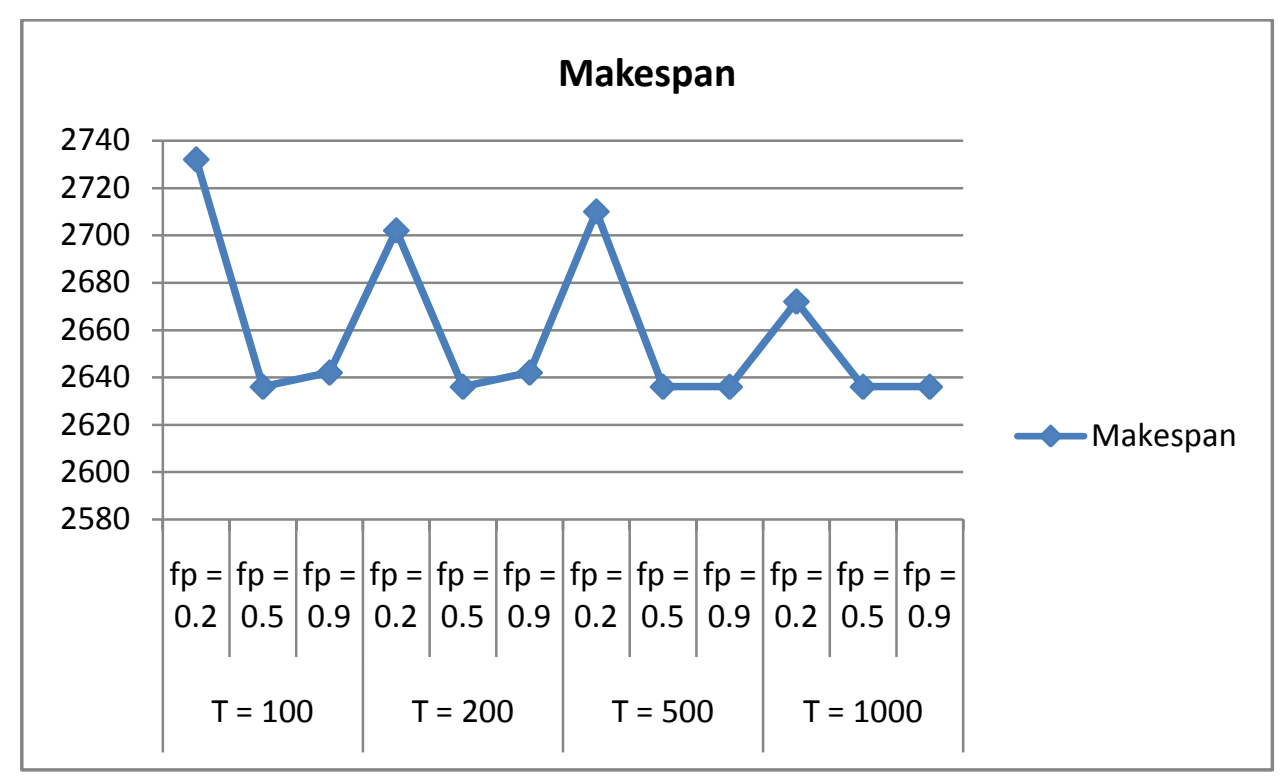

Gambar 3

Grafik Perbandingan T 100, T 200, T 500, dan T 1000 dengan makespan

Pada grafik diatas untuk suhu (T) 100 dengan menggunakan fp 0.2 menghasilkan makespan yang sangat tinggi yaitu 2732 menit. Hal ini dikarenakan penurunan suhu yang sangat cepat sehingga banyak pencarian solusi optimum yang terlewati. Untuk T 100 dengan menggunakan fp 0.5 menghasilkan makespan yang rendah yaitu 2636 menit. Hal ini menunjukkan bahwa dengan menaikkan faktor pereduksi maka penurunan suhunya tidak terlalu cepat dan pencarian solusi optimalnya bisa lebih banyak lagi sehingga menghasilkan makespan yang lebih kecil dari yang sebelumnya. Pada T 100 dengan menggunakan fp 0.9 didapat makespan sebesar 2642 menit. Makespan ini lebih besar dari yang sebelumnya yang hanya menghasilkan 2636 menit. Hal ini dikarenakan dari bilangan random yang dibangkitkan pada saat pencarian solusi optimal juga berpengaruh pada hasil makespan dari setiap parameter suhu (T) dan faktor penurunan/pereduksi suhu (fp).

Pada suhu (T) 200 dengan menggunakan fp 0.2 menghasilkan makespan yang cukup tinggi yaitu 2702 menit. Hal ini dikarenakan penurunan suhu yang sangat cepat sehingga banyak pencarian solusi optimum yang terlewati. Untuk T 200 dengan menggunakan fp 0.5 menghasilkan makespan yang rendah yaitu 2636 menit. Hal ini menunjukkan bahwa kenaikkan faktor pereduksi maka penurunan suhunya tidak terlalu cepat dan pencarian solusi optimalnya bisa lebih banyak lagi sehingga menghasilkan makespan yang lebih kecil dari yang sebelumnya. Pada T 200 dengan menggunakan fp 0.9 didapat makespan sebesar 2642 menit. Makespan ini lebih besar dari yang sebelumnya yang hanya menghasilkan 2636 menit. Hal ini dikarenakan dari bilangan random yang dibangkitkan pada saat pencarian solusi optimal juga berpengaruh pada hasil makespan dari setiap parameter suhu (T) dan faktor penurunan/pereduksi suhu (fp).

Pada suhu (T) 500 dengan menggunakan fp 0.2 menghasilkan makespan yang cukup tinggi yaitu 2710 menit. Ini lebih besar dari pada T sebelumnya karena meskipun 
$\mathrm{T}$ dinaikkan sedangkan fp menggunakan 0.2 penurunan suhu yang cepat akan mempersempit hasi pencarian solusi optimum. Untuk T 500 dengan menggunakan fp 0.5 menghasilkan makespan 2636 menit. Hal ini menunjukkan bahwa kenaikkan faktor pereduksi maka penurunan suhunya tidak terlalu cepat dan pencarian solusi optimalnya bisa lebih banyak lagi sehingga menghasilkan makespan yang lebih kecil dari yang sebelumnya. Juga pada T 500 dengan menggunakan fp 0.9 menghasilkan makespan yang sama yaitu 2636 menit.

Sedangkan pada suhu (T) 1000 dengan menggunakan fp 0.2 menghasilkan makespan sebesar 2672 menit. Makespan ini tidak terlalu besar jika dibandingan pada fp 0.2 di T sebelumnya karena untuk T 1000 hasil pencarian solusi optimum lebih banyak dari pada sebelumnya. T 1000 dengan menggunakan fp 0.5 menghasilkan makespan 2636 menit. Hal ini menunjukkan bahwa fp 0.5 menunjukkan kestabilannya karena penurunan suhunya tidak terlalu banyak juga tidak terlalu rendah. Begitu juga pada T 1000 dengan menggunakan fp 0.9 menghasilkan makespan yang sama yaitu 2636 menit karena hasil pencarian solusi bisa lebih banyak.

Dari analisa diatas fp sangat berpengaruh pada jumlah makespan yang dihasilkan. Jika suhu rendah dan digunakan fp rendah juga maka hasil dari makespan juga tinggi karena banyak titik optimal yang terlewati, jika suhu tinggi digunakan fp rendah juga masih belum bisa menemukan titik yang paling optimal. Sedangkan jika menggunakan T 0.5 suhu yang diturunkan tidak terlalu besar juga tidak terlalu tinggi, untuk semu T menghasilkan makespan yang sama yaitu 2636 menit. Dan untuk penggunaan fp tinggi yang berpengaruh hanya pada yang cukup tinggi pula yaitu pada T 500 dan 1000. Hal ini juga dipengaruhi oleh bilangan random yang dibangkitkan ketika pencarian solusi baru. Sehingga untuk solusi terbaik dilihat dari makespannya didapat pada T 100, 200, 500, dan 1000 pada fp 0.5 juga pada T 500, dan T 1000 pada fp 0.9 dengan makespan sama yaitu 2636 menit.

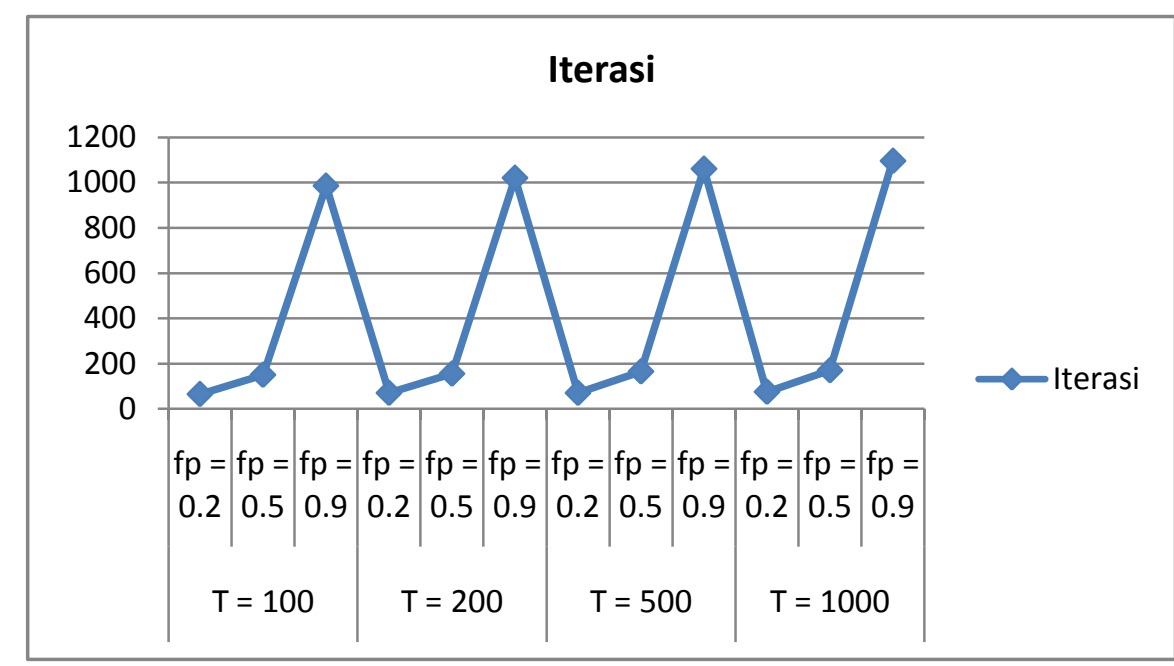

Gambar 4

Grafik Perbandingan T 100, T 200, T 500, dan T 1000 dengan Jumlah Iterasi

Pada grafik diatas untuk suhu (T) 100 dengan menggunakan fp 0.2 menghasilkan iterasi sebanyak 66 iterasi. Hal ini dikarenakan penurunan suhu yang sangat cepat sehingga pada iterasi tersebut sudah mencapai steadi state. Untuk T 100 dengan menggunakan fp 0.5 menghasilkan 151. Hal ini menunjukkan bahwa dengan menaikkan faktor pereduksi maka iterasi yang dihasilkan juga semakin banyak dari pada sebelumnya. Pada T 100 dengan menggunakan fp 0.9 didapat iterasi sebanyak 986. Iterasi ini lebih besar dari 
yang sebelumnya karena jumah iterasi sangat berpengaruh pada setiap parameter suhu (T) dan faktor penurunan/pereduksi suhu (fp) yang digunakan

Begitu juga pada T 200 T 500 dan T100, setiap terjadi kenaikan pada fp maka jumlah iterasi yang dihasilkan juga semakin banyak. Untuk bilangan random yang dibangkitkan pada pencarian solusi tidak berpengaruh karena $\mathrm{T}$, fp dan iterasi berbanding lurus. Bisa dilihat pada grafik 5.3 setiap $\mathrm{T}$ yang dinaikkan dan fp yang dinaikan maka jumlah iterasi yang dihasilkan juga semakin banyak.



Gambar 5

Grafik Perbandingan T 100, T 200, T 500, dan T 1000 dengan Waktu Komputasi

Pada grafik diatas untuk suhu (T) 100 dengan menggunakan fp 0.2 menghasilkan waktu komputasi 0.0156 detik. Hal ini dikarenakan penurunan suhu yang sangat cepat dan proses pencarian solusi juga akan cepat selesai. Untuk T 100 dengan menggunakan fp 0.5 menghasilkan waktu komputasi sama 0.0156 dalam hal ini pembangkitan dari bilangan random untuk penggunaan aturan pengacakan juga berpengaruh karena jika pengacakan semakin sulit maka akan dibutuhkan waktu yang lama sesuai dengan aturan pengacakan yang sudah dibahas pada bab sebelumnya. Pada T 100 dengan menggunakan fp 0.9 didapat wktu komputasi yang lebih lama dari fp sebelumnya yaitu 0.1404 detik karena pencarian solusi juga semakin banyak, oleh karena itu setiap faktor penurunan/pereduksi suhu (fp) yang digunakan juga mempengaruhi waktu komputasi yang dihasilkan.

Pada suhu (T) 200 dengan menggunakan fp 0.2 menghasilkan waktu komputasi 0.0312 detik. Waktu komputasi ini juga sama untuk T 200 dengan menggunakan fp 0.5 yang juga menghasilkan waktu komputasi 0.0312 detik, dalam hal ini pembangkitan dari bilangan random untuk penggunaan aturan pengacakan juga berpengaruh karena jika pengacakan semakin sulit maka akan dibutuhkan waktu yang lama sesuai dengan aturan pengacakan yang sudah dibahas pada bab sebelumnya. Pada T 200 dengan menggunakan fp 0.9 didapat waktu komputasi yang lebih lama dari fp sebelumnya yaitu 0.1248 detik karena pencarian solusi juga semakin banyak, tapi jika dibandingkan dengan fp 0.9 pada $\mathrm{T}$ sebelumnya hasilnya lebih kecil karena pembangkitan dari bilangan random untuk penggunaan aturan pengacakan juga berpengaruh karena jika pengacakan semakin sulit maka akan dibutuhkan waktu yang lama sesuai dengan aturan pengacakan yang sudah dibahas pada bab sebelumnya.

Pada suhu (T) 500 dengan menggunakan fp 0.2 menghasilkan waktu komputasi 0.0156 detik. Untuk waktu komputasi pada T 500 dengan menggunakan fp 0.5 menghasilkan waktu komputasi 0.0412 detik, lebih besar dari fp sebelumnya. Pada T 
500 dengan menggunakan fp 0.9 didapat waktu komputasi yang lebih lama dari fp sebelumnya yaitu 0.1404 , dengan ini pada T 500 seiring dengan peningkatan fp maka waktu komputasi yang dihasilkan juga semakin tinggi.

Sedangkan pada suhu (T) 1000 Pada dengan menggunakan fp 0.2 menghasilkan waktu komputasi 0.0312 detik. Untuk waktu komputasi pada T 1000 dengan menggunakan fp 0.5 menghasilkan waktu komputasi 0.0468 detik, lebih besar dari fp sebelumnya. Pada T 200 dengan menggunakan fp 0.9 didapat waktu komputasi yang lebih lama dari fp sebelumnya yaitu 0.1248 dan lebih kecil dari pada fp 0.9 pada $\mathrm{T}$ sebelumnya, hal ini dikarenakan pembangkitan dari bilangan random untuk penggunaan aturan pengacakan juga berpengaruh karena jika pengacakan semakin sulit maka akan dibutuhkan waktu yang lama sesuai dengan aturan pengacakan yang sudah dibahas pada bab sebelumnya. Dengan ini pada T 1000 seiring dengan peningkatan fp maka waktu komputasi yang dihasilkan juga semakin tinggi.

Pada suhu (T) dengan peningkatan fp maka waktu komputasi yang dihasilkan cenderung lebih besar meskipun masih ada yang dalam peningkatan fp tersebut waktu komputasinya tetap. Begitu juga pada peningkatan suhu (T) waktu komputasi yang dihasilkan juga semakin banyak meskipun juga ada salah satu yang lebih kecil tapi keseluruhan cenderung waktu komputasinya naik. Hal ini dikarenakan pembangkitan dari bilangan random untuk penggunaan aturan pengacakan juga berpengaruh karena jika pengacakan semakin sulit maka akan dibutuhkan waktu yang lama sesuai dengan aturan pengacakan yang sudah dibahas pada bab sebelumnya.

\section{Perbandingan Penjadwalan Perusahaan Dengan Penjadwalan Simulated Annealing}

Untuk mengetahui apakah metode usulan SA lebih baik dari metode yang diterapkan perusahaan saai ini maka akan dilakukan pengukuran terhadap parameter performance yang dilihat dari perhitungan nilai performance dan efisien. Untuk mengetahui performance parameter yang digunakan dengan menentukan metode yang lebih baik digunakan pendekatan dengan mengukur nilai efisiensi. Efisiensi digunakan untuk mengetahui seberapa besar efisiensi dari perbedaan makespan yang dihasilkan oleh kedua metode. Untuk mengetahui nilai efisiensi menggunakan rumus:

$$
\text { Efisiensi }=\frac{Z_{\text {Makespan Perusahaan }}-\mathrm{Z}_{\text {Makespan SA }}}{\mathrm{Z}_{\text {MakespanPerusahaan }}} \times 100 \%
$$

Dalam perhitungan makespan sebelumnya telah didapatkan bahwa total makespan metode usulan SA sebesar 2636 menit, sedangkan metode perusahaan didapatkan total makespan sebesar 2917 menit. Maka besar parameter performance efisiensi adalah sebagai berikut:

$$
\begin{gathered}
\text { Efisiensi }=\frac{2917-2636}{2636} \times 100 \% \\
\text { Efisiensi }=10,66 \%
\end{gathered}
$$

Dalam perhitungan makespan sebelumnya telah didapatkan bahwa total makespan metode usulan SA sebesar 2636 menit, sedangkan metode perusahaan didapatkan total makespan sebesar 2917 detik. Maka selisih total makespan sebesar 281 detik atau berkisar 5 jam. Berdasarkan hasil perhitungan nilai efisiensi, didapatkan nilai sebesar $10,66 \%$ yang artinya bahwa metode SA menunjukkan lebih efisien dan lebih baik dibanding dengan metode yang diterapkan oleh perusahaan saat ini berdasarkan nilai makespannya. Berikut ini tabel hasil perbandingan metode usulan SA dengan metode yang dipakai perusahaan. 
Selain makespan juga didapat idle time setiap mesin pada penjadwalan awal perusahaan dan penjadwalan dengan simulated annealing (SA). Berikut hasil perhitungan efisiensi dari idle time tiap mesin.

Tabel 2 Perbandingan Idle Time Metode SA dengan kondisi awal

\begin{tabular}{lllll}
\hline Mesin & Idle time awal & Idle time SA & Selisih & Efisiensi \\
\hline $\mathbf{1}$ & 1839 & 1558 & 281 & $2.81 \%$ \\
$\mathbf{2}$ & 1562 & 1281 & 281 & $2.81 \%$ \\
$\mathbf{3}$ & 1007 & 726 & 281 & $2.81 \%$ \\
$\mathbf{4}$ & 902 & 621 & 281 & $2.81 \%$ \\
$\mathbf{5}$ & 2461 & 2180 & 281 & $2.81 \%$ \\
\hline
\end{tabular}

Berdasarkan hasil perhitungan nilai efisiensi, didapatkan nilai sebesar 22,07\% yang artinya bahwa metode SA menunjukkan lebih efisien dan lebih baik dibanding dengan metode yang diterapkan oleh perusahaan saat ini berdasarkan total idle timenya. Berikut ini tabel hasil perbandingan metode usulan SA dengan kondisi awal.

Tabel 3 Perbandingan Metode SA Dengan kondisi awal

\begin{tabular}{llll}
\hline \multicolumn{4}{c}{ Perbandingan Metode SA Dengan kondisi awal } \\
\hline NO. & Parameter & SA & Kondisi awal \\
1 & Urutan job optimal & $5-7-2-1-3-8-6-4$ & $1-2-3-4-5-6-7-8$ \\
2 & Makespan & $49 \mathrm{jam}$ & 44 jam \\
3 & Selisih waktu & $5 \mathrm{jam}$ & \\
4 & Efisiensi makespan & $10,66 \%$ & \\
5 & Efisiensi idle time & $2.81 \%$ tiap mesin & \\
\hline
\end{tabular}

\section{KESIMPULAN}

Dari hasil pengolahan data dan analisa sensitivitas yang telah dilakukan, maka kesimpulan bahwa Penjadwalan produksi dengan metode Simulated Annealing (SA) dari analisa pada pembahasan sebelumnya didapat solusi pada parameter suhu (T) 100 dan parameter faktor penurunan suhu (fp) 0.5 menghasilkan makespan sebesar 2.636 menit $\approx 44$ jam.

Dari hasil perbandingan pada pembahasan sebelumnya penjadwalan yang dilakukan oleh perusahaan menghasilkan makespan sebesar 2917 menit $\approx 49$ jam. Maka hasil makespan penjadwalan dengan metode SA lebih baik dengan selisih waktu 5 jam hampir mendekati 1 hari jam kerja kondisi sebelumnya. Selain makespan juga didapat idle time dari metode SA lebih baik yaitu $2.81 \%$ pada tiap mesin.

\section{DAFTAR PUSTAKA}

[1] Baker, Kenneth R. 1974. Principles Of Sequencing and Scheduling. America : John Wiley and Son Inc.

[2] Ginting, Rosnani. 2009. Penjadwalan Mesin. Yogyakarta : Graha Ilmu

[3] Uttari, Saria. Skripsi, 2008. "Usulan penJadwalan produksi produk manframe pada mesin punch exentrik". Fakultas Teknik, Universitas Pembangunan Nasional “ Veteran". Jakarta

[4] Nasution, Arman Hakim. 1999. Perencanaan dan Pengendalian Produksi. Surabaya : Guna Widya

[5] Santosa, Budi dan Willy, Paul. 2011. Metoda Metaheuristik Konsep dan Implementasi. Surabaya : Guna Widya 
[6] Damanik, Dian Amru. Skripsi, 2011. "Penjadwalan Produksi dengan metode Simulated Annealing Pada Unit Produksi Daun Pintu di PT. Mahogany Lestari”. Fakultas Teknik, Universitas Sumatera Utara. Medan

[7] Ratnasari, Aditya. 2007. "Implementasi Algoritma Simulated Annealing Dalam Penyelesaian Masalah Penjadwalan Produksi Jenis Flowshop".Fakultas Teknik Universitas Kristen Duta Wacana

[8] Rofiq, Ainur 2013. Skripsi, 2013. "Pengembangan Algoritma Simulated Annealing Pada Permasalahan Hybrid Flowshop Scheduling Untuk Meminimasi Makespan dan Total Tardines". Fakultas Teknik Universitas Sepuluh November Surabaya. 